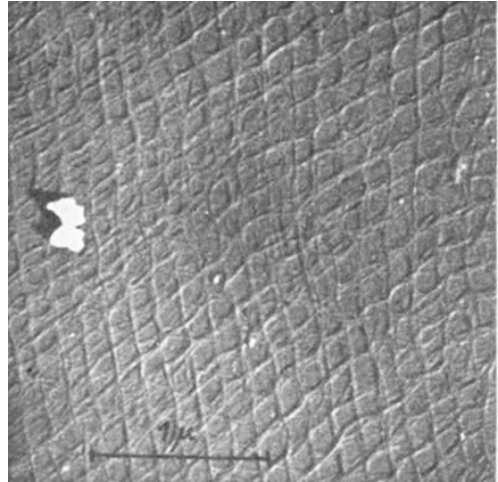

Fig. 1

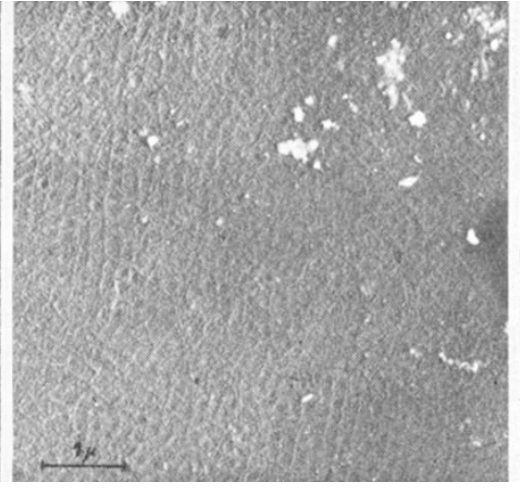

Fig. 2



Fig. 3

Fig. 1. Regular network from the excrement of the larva of clothes moth. Shadowed with gold-manganin

Fig. 2. Continuous membrane in which the regular 'fishing-net' pattern can be recognized. Shadowed with gold-manganin Fig. 3. Arbitrarily arranged fibrils. Shadowed with gold-manganin

found them in the excrement from larvæ fed on a diet free from wool. These networks seem to be similar to the structures in Dixippus morosus recently reported by Huber and Haasser1.

Gösta Lagermatm

Bo PHILIP

Nils Gralén

Swedish Institute for Textile Research, Gothenburg.

April 28.

${ }^{1}$ Huber, W., and Haasser, C., Nature, 165, 397 (1950).

\section{A Localized Effect of Light on the Proto- plasmic Viscosity of Plant Cells}

IF one half of a leaf of Elodea densa is illuminated, the other half being screened off, a decrease in the permeability strictly localized to the illuminated area is observed ${ }^{1}$. This area accumulates methylene blue considerably more strongly than the unilluminated area.

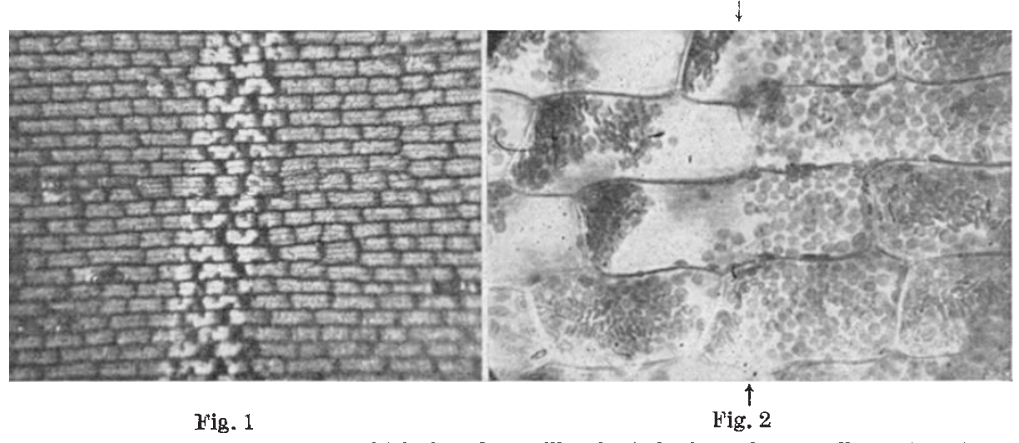

Fig. 1. A leaf of Elodea densa which has been illuminated through a small aperture in a

Fig. 2. Some centrifuged cells of Helodea densa of which part has been illuminated. The illuminated area is seen to the left of the arrows
It has now been found that this decrease in the viscosity is strictly confined to that part of the leaf that has been illuminated. Thus, if a leaf of Elodea is covered with a strip of tinfoil in which a small aperture with even edges is cut, and the leaf is centrifuged after illumination, only that part of the leaf under the aperture in the tinfoil has been affected (Fig. 1). Closer examination of the cells adjacent to the edges of the aperture reveals occasional cells only part of which has been illuminated. It is found that the viscosity is decreased only in illuminated parts of the cells, the unilluminated parts being unaffected (Fig. 2). This is thus an example of a reaction in which the site of the perception of stimulus and of the reaction is the same.

It has been shown earlier ${ }^{2-4}$ that changes in the viscosity of the plasma due to light constitute a reaction which is in all probability a general phenomenon. The above observations with respect to the localized effect of the light energy appliedwhich is evidently intimately connected with the changes in permeability - suggest an explanation of the phototropic phenomena in polar organs such as the coleoptile of Avena, which has a polar stream of hormones. Unilateral illumination of such an orgain causes changes in the viscosity and the permeability respectively of the plasma in the cells treated. This may possibly be the reason for the unequal distribution of the stream of hormones originating in the tip of the organ.

Further details of these ex. periments with respect to the viscosity changes in illuminated plant cells will be published later.

Hemming I. Virgin
Illumination of cells with strong visible light (for example, 22,000 m.c. incandescent light) also causes an appreciable decrease in the viscosity of the plasma. This is demonstrable by the fact that the cell contents, such as the plasma with its component plastids, of cells which have been illuminated can be made to move considerably more easily under the influence of centrifugal force than those of unilluminated cells ${ }^{2-5}$.
Institute of Physiological Botany, University of Stockholm.

$$
\text { May } 2 .
$$

${ }^{1}$ Lepeschkin, W. W., Amer. J. Bot., 17, 953 (1930).

${ }^{2}$ Stålfelt, M. G., Arkiv Botan., A 33, No. 4 (1946).

${ }^{s}$ Virgin, H. I., Physiol. Plant, 1, 147 (1948).

"Virgin, H. I., Exp. Cell Res., Supp. 1, 79 (1949).

'Voerkel, H., Planta, 21, 156 (1934). 